\title{
FUNGSI MEDIA MASSA DALAM HEGEMONI MEDIA
}

\author{
${ }^{1}$ Shinta Hartini Putri, ${ }^{2}$ Shafira Afranisa Yusian \\ Fakultas Komunikasi dan Desain, Universitas Informatika dan Bisnis Indonesia \\ Email : shintahartiniputri@unibi.ac.id ${ }^{1}$, shafira.afranisa@gmail.com² ${ }^{2}$
}

\begin{abstract}
Abstrak
Media massa di Indonesia saat ini tidak mejalankan fungsi sebagaimana mestinya karena adanya kepemilikan media (penguasa media). Salah satu fenomena yang banyak dibicarakan masyarakat Indonesia adalah salah satu lembaga media yang mengkoordinasi medianya digunakan untuk kepentingan berkampanye pemilik media melalui mars partainya. Secara tidak langsung yang dilakukan media ketika mereka memihak suatu pihak (penguasa media untuk berpolitik) mereka telah menghegemoni masyarakat atas yang apa mereka lakukan. Dengan kata lain, tindakan yang dilakukan media (penguasanya) adalah proses doktrin secara halus kepada masyarakat, agar terbuai akan imingiming hal yang di tayangkan media (khususnya pada televisi, karena visual lebih menggambarkan suatu pesan), sehingga khalayak tidak merasa tertindas, dan menganggap yang dilakukan media tidak berpengaruh dan diterima secara wajar.
\end{abstract}

Kata kunci: Media massa, hegemoni media

\section{Abstract}

The mass media in Indonesia currently do not function properly because of media ownership (media rulers). One of the phenomena that are widely talked about by the Indonesian people is one of the media institutions coordinates the media used for the purpose of campaigning for media owners through the march of their parties. Indirectly carried out by the media when they side with a party (the media authority to engage in politics) they have hegemony the community for what they are doing. In other words, the actions taken by the media (its rulers) are subtle doctrinal processes to the community, so that they are lulled by the lure of the media (especially on television), because visuals better describe a message), so that the audience doesn't feel oppressed, and assume that what the media doesn't have an effect and is accepted fairly.

Keywords: Mass media, hegemony media 


\section{PENDAHULUAN}

Manusia sebagai makhluk sosial senantiasa ingin selalu berinteraksi dengan manusia lainnya. Ia ingin mengetahui apa yang terjadi di lingkungan sekitarnya. Rasa ingin tahu itu yang memotivasi dirinya untuk mencari dan memaksa untuk perlu berkomunikasi. Dilihat dari fungsinya sendiri, komunikasi berfungsi untuk menyampaikan pesan atau argumen tentang sesuatu yang hendak dikemukakan. Tidak hanya interaksi antar individu, tetapi informasi pun mengalir lewat jenis komunikasi lainnya, salah satunya adalah komunikasi massa.

Komunikasi massa merupakan salah satu komunikasi yang melibatkan banyak pihak. Media massa (cetak, dan elektronik) sendiri adalah sarana penyampaiannya. Pada masa ini, media massa khususnya di Indonesia, banyak berperan diluar fungsinya sebagai sarana informasi. Hal itu terjadi karena suatu kepemilikan media yang membuat media tidak bekerja sesuai fungsinya, karena di dalamnya terdapat unsur kepentingan lain (terutama unsur politik) yang dirasa bukan seharusnya sebuah media massa seperti itu. Banyak masyarakat yang tidak menyadari adanya hal tersebut, dikarenakan kurangnya sosialisasi kepada masyarakat oleh pemerintah tentang hukum dan ketentuan penyiaran yang berlaku di Indonesia.

Kurangnya kesadaran masyarakat akan hal yang terjadi bisa dilihat dari masyarakat yang tidak merasa dirugikan akan hal berkepentingan lain yang dilakukan media massa saat ini. Jika dilihat peran media saat ini, media massa (cetak atau elektronik) tidaklah efektif sebagai media penyampaian, yang secara tidak langsung mengubah pola pikir dan perilaku khalayak untuk menerima hal berkepentingan lain tersebut. Dari beberapa informasi yang ada khususnya melalui salah satu media yaitu televisi, banyak sekali tayangan-tayangan yang memperlihatkan kepemilikan media, baik dari sisi berpolitik ataupun lainnya. Hal tersebut bisa dikatakan sebagai hegemoni media massa, dimana media massa lebih tunduk terhadap kepemilikan medianya dibandingkan dengan ketentuan hukum yang berlaku di
Indonesia. Dari fenomena yang ada tentang kepemilikan media itu sendiri, tidak hanya satu kepemilikan media memiliki satu stasiun televisi, namun banyak stasiun televisi yang dimiliki oleh satu kepemilikan media (penguasaan media), dan tidak hanya televisi saja yang menjadi sasaran sang penguasa media, tetapi media lain pun seperti radio dan media cetak yang ada menjadi sasarannya. Dengan banyaknya penguasaan media, membuat media secara tidak langsung beralih fungsi menjadi ladang berbisnis, atau dengan kata lain, media massa saat ini sudah tidak sesuai fungsinya sebagai sarana informasi, melainkan sebagai bisnis yang dilakukan oleh penguasa media guna mendapatkan perhatian lebih dari masyarakat luas.

Karena itu, dengan adanya hegemoni media saat ini (penguasaan media) media massa sudah tidak berfungsi dengan baik, tidak sesuai dengan tugasnya sebagai sarana informasi, dimana seharusnya media massa memberikan contoh yang positif untuk masyarakat luas, bukan malah melakukan apa yang diminta oleh sang penguasa demi kepentingan pribadi. Oleh karena itu, permasalahan yang akan diuraikan dalam tulisan ini adalah bagaimana fungsi media massa seharusnya pada saat ini dalam hegemoni media.

\section{TINJAUAN PUSTAKA}

\subsection{Media Massa}

Media massa adalah sarana atau perantara sebuah informasi yang akan dipublikasikan kepada khalayak (masyarakat luas). Media massa sendiri merupakan sebuah alat-alat komunikasi mekanis seperti surat kabar, film, radio, dan televisi. Atau dengan kata lain media massa adalah alat komunikasi yang dapat menyebarluaskan pesan secara serempak, cepat kepada khalayak yang heterogen.

Menurut McQuail, media massa memiliki fungsi sebagai pusat informasi, yang berperan sebagai penyedia dan penyampai informasi mengenai berbagai macam peristiwa, kejadian, realitas, dan banyak hal lain yang terjadi di tengah masyarakat. Oleh karena itu di dalam media massa mesti 
terdapat fakta-fakta atau kejadian-kejadian tertentu yang dilaporkan oleh media massa untuk diketaui oleh masyarakat yang membaca berita tersebut (2012). Tidak hanya sebagai fungsi informasi, ada beberapa pakar komunikasi mengemukakan tentang fungsi media massa sebagai berikut:

A. Fungsi Komunikasi Massa menurut Dominick (2002):

1)Pengawasan (Surveillance): Fungsi pengawasan dibagi menjadi 2 yaitu: warning or beware surveillance yaitu ketika terjadi ancaman seperti bencana alam, dll maka media akan melakukan fungsi peringatan kepada masyarakat. Dan instrumental surveillance adalah penyampaian atau penyebaran informasi yang memiliki kegunaan untuk membantu khalayak dalam kehidupan sehari-hari.

2) Penafsiran (Interpretation): Media massa memberikan penafsiran terhadap kejadian-kejadian penting dengan tujuan mengajak khalyak luas untuk memperluas wawasan.

3) Pertalian (Linkage): Media massa dapat menyatukan anggota masyarakat sehingga membentuk suatu pertalian berdasarkan kesamaan kepantingan dan minat.

4) Penyebaran Nilai-Nilai (Transmission of Values): Disebut juga dengan sosialisasi (sosialization) yaitu cara seseorang mengadopsi perilaku dan nilai kelompok. Media massa berperan dalam menyebarkan nilai-nilai kepada masyarakat. Melalui nilai-nilai tersebut perilaku dan kepribadian seseorang dapat berubah seperti yang disampaikan oleh media.

5) Hiburan (Entertainment)

B. Fungsi Komunikasi Massa menurut Effendy (1993)

1) Fungsi Informasi: media massa adalah penyebar informasi yang paling dibutuhkan karena keakuratan, kecepatan penyebaran dan tidak terbatas.
2) Fungsi Pendidikan: Media massa merupakan sarana yang efektif untuk mendidik para khalayaknya melalui penyebaran nilai, etika dan aturan.

3) Fungsi Mempengaruhi: Media massa dapat mempengaruhi khalayak.

C. Fungsi Komunikasi Massa menurut DeVito (1996)

1) Fungi Meyakinkan (to persuade): ada 4 fungsi meyakinkan yaitu mengukuhkan, mengubah, menggerakkan dan menawarkan etika.

a. Mengukuhkan, adalah suatu usaha untuk mengubah atau mempertahankan sikap dan kepercayaan khalayak sebagai upaya agar mereka bertindak dengan cara tertentu.

b. Mengubah, yaitu usaha media untuk mengubah khalayak yang tidak memihak pada suatu permasalahan tertentu menjadi condong ke salah satu sisi.

c. Menggerakkan, media berusaha mengajak pembaca atau pemirsa untuk membentuk suatu sikap dan mengendalikan sikap tersebut ke arah tertentu.

d. Menawarkan Etika, Mengungkapkan penyimpanganpenyimpangan tertentu sehingga merangsang masyarakat untuk mengubah situasi.

2) Fungsi Menganugerahkan Status: Terjadi apabila berita yang disebarkan melaporkan kegiatan individu sehingga dapat meningkatkan prestige (gengsi) mereka. Komunikasi Massa juga memiliki fungsi untuk memberi atau meperkuat kontro sosial di masyarakat.

3) Fungsi Membius (Narcotization): Media menyajikan informasi kepada khalayak yang dapat mempengaruhi dan percaya bahwa suatu tindakan harus diambil untuk menanggapi kasus atau berita tersebut. 
4) Fungsi Menciptakan Rasa Kebersatuan: Komunikasi massa mampu membuat seseorang merasa menjadi anggota atau bagian dari suatu kelompok.

5) Fungsi Privatisasi: Berlimpahnya informasi dapat membuat seseorang menarik diri dari pergaulan 1 .

\subsection{Teori Hegemoni}

Perkembangan media massa saat ini sangatlah pesat, karena media massa sendiri adalah arus utama sumber informasi yang dikonsumsi setiap harinya oleh kita selaku khlayak. Dan media massa sendiri memiliki pengaruh yang sangat besar untuk masyarakat, termasuk salah satunya adalah hegemoni media massa.

Kata Hegemoni berasal dari bahasa Yunani kuno yaitu, egemonia yang artinya penguasa atau pemimpin. Jadi hegemoni adalah suatu bentuk kekuasaan atau kepemimpinan pada suatu kelompok tertentu dengan cara kepemimpinan intelektual yang didominasi oleh nilai-niali sosial, prinsipprinsip kehidupan yang dianut oleh si penguasa kepada khalayak. Hegemoni menurut pandangan Antonio Gramsci, dominasi dalam masyarakat yang terjadi melalui proses pembudayaan sehingga menghilangkan kesadaran masyarakat atau budaya yang terdominasi atas dominasi yang dilakukan (Maryani, 2011: 53). Maka hegemoni tidak dapat dipisahkan dari konteks yang memosisikan kelompok penguasa yang mampu menimbulkan keyakinan di sejumlah masyarakat. Dengan kata lain hal yang dilakukan penguasa adalah pendoktrian secara halus kepada khalayak, sehingga khalayak senantiasa menganggap hal yang dilakukan penguasa adalah hal lumrah yang tidak merugikan mereka.

\subsection{Hegemoni Media}

Merujuk dari pemahaman tentang hegemoni. Hegemoni sendiri telah lekat kaitannya dengan media massa saat ini, khususnya di Indonesia. Dimana saat ini ini telah banyak penguasa media yang menggunakan medianya untuk kepentingan pribadi penguasa (hegemoni media), dengan kata lain para penguasa media telah mendoktrin secara halus kepada masyarakat, dan masyarakat pun tidak menyadari adanya maksud pendoktrinan secara halus tersebut. Hal itu dikarenakan kurangnya sosialisasi tentang ketentuan-ketentuan tayangan televisi dari pemerintah kepada masyarakat, sehingga masyarakat kini kurang menyadari akan halhal kecil namun dapat berpengaruh terhadap pola pikir dan perilaku mereka.

\subsection{Teori Normatif menurut Denis McQuail dalam Teori Hegemoni}

Dalam pengertiannya teori normatif media (normative theory of media) meliputi baik tujuan yang ditetapkan secara internal maupun klaim dari luar mengenai bagaimana seharusnya media berprilaku (McQuail, 2012: 178). Teori normatif ini berkenaan dengan masalah bagaimana seharusnya media berperan ketika serangkaian nilai sosial ingin diterapkan dan dicapai sesuai dengan sifat dasar nilai-nilai sosial. Teori hegemoni ini berkaitan dengan nilai-nilai dalam kehidupan, seperti teori normatif yang menganut sistem nilai sosial politik/pemerintah, dengan kepentingan ditujukan kepada khalayak. Namun perbedaannya, hegemoni menganut nilai-nilai sosial tersebut untuk kepentingan politik (penguasa media)

Dalam dunia politik, media massa berfungsi untuk mengawasi penguasa (mengkritik). Saat ini media massa malah digunakan sebagai alat untuk menyebarluaskan kekuasaannya kemudian diterima secara luas oleh masyarakat dan menjadi sebuah hal yang biasa. 


\section{PEMBAHASAN}

Media massa di Indonesia saat ini tidak mejalankan fungsi sebagaimana mestinya, karena adanya kepemilikan media (penguasa media). Salah satu fenomena yang banyak dibicarakan masyarakat Indonesia adalah dimana salah satu lembaga media yang mengkoordinasi medianya yang secara tidak langsung untuk kepentingan berkampanye sang pemilik media lewat mars partainya, hal tersebut dilakukan dari November 2015 sampai Januari 2016 di 3 stasiun televisi miliknya sebanyak $1918 \mathrm{kali}^{2}$. Hal tersebut dirasa menghegemoni (mendoktrin secara halus) masyarakat untuk selalu mengingat partainya dan menjadikannya pilihan saat pemilu yang akan datang.

Fungsi komunikasi secara umum adalah untuk menyampaikan sebuah informasi dari komunikator kepada komunikan, arti komunikator sendiri adalah si pemberi pesan, sedangkan komunikan ada si penerima pesan. Sama halnya dengan komunikasi massa, hanya saja komuniksi massa cara penyampaian informasinya menggunakan perantara media (cetak dan elektronik). Ada 3 fungsi komunikasi massa menurut Effendy (1993):

1. Informasi: media massa sebagai sarana penyebaran informasi yang paling dibutuhkan karena keakuratannya, kecepatan tersebarnya informasi dan tidak terbatas,

2. Pendidikan: sebagai sebuah sarana edukatif karena didalamnya terdapat nilai etika dan aturan yang mendidik khalayak,

3. Mempengaruhi: pesan moral, nilai-nilai sosial yang ada pada media massa dapat mempengaruhi khalayak (pola pikir ataupun perilaku) ${ }^{3}$.

Merujuk dari pemahaman Gramsci tentang hegemoni yang dilakukan media, memang fungsi-fungsi dari komunikasi massa sendiri sangat jelas. Namun dibalik fungsinya yang utuh sesuai pendapat Effendy, banyak unsur-unsur kepentingan lain. Bisa dilihat dari

2 Tirto. Menancapkan Mars Perindo lewat Stasiun TV milik Pribadi. Melalui <https://tirto.id/menancapkan-marsperindo-lewat-stasiun-tv-milik-pribadi-nn $>$ (diakses pada tanggal 23 Januari 2018, Pukul 23.49 WIB). beberapa proses komunikasi medianya (media massa, khususnya televisi), sistem penyiaran di Indonesia saat ini banyak sekali penguasa media (kepemilikan media) menggunakan medianya sebagai sarana berpolitik (berkampanye). Padahal dari fungsi utuh sebuah media massa adalah sebagai sarana informasi. Memang yang ditayangkan media adalah informasi tentang suatu berita, tetapi jika isi berita tersebut selalu berujung kepada unsur kampanye yang secara tidak langsung khlayak menikmatinya, dan khalayak sudah menganggap hal tersebut lumrah, sudah bukan lagi fungsi media sebagai sarana informasi, karena sudah sangat melenceng dari fungsinya.

Beberapa media penyiaran di Indonesia khususnya pertelevisian sudah tidak berfungsi sebagaimana mestinya sebagai sarana pendidikan. Karena saat ini banyaknya program acara yang disiarkan di beberapa stasiun televisi sendiri tidak memiliki nilainilai sosial, pesan moral, etika atau aturan yang dapat membantu mendidik khalayak yang menikmatinya, terutama anak dibawah umur. Kebanyakan tayangan-tayangan yang disiarkan cenderung mengarah kepada hal-hal negatif (contoh: sinetron yang menanyangkan kisah percintaan remaja, padahal tidak seharusnya begitu, karena khlayak yang menikmatinya pun bukan remaja saja).

Fungsi media massa sebagai media yang mempengaruhi. Program acara yang ada di pertelevisian di Indonesia saat ini sangat mempengaruhi khalayak, namun lebih kepada mempengaruhi dalam arti negatif. Banyaknya tayangan-tayangan yang dirasa kurang bermutu, membuat banyak khalayak yang salah memilih pesan-pesan yang disampaikan. Salah satunya program acara gosip yang hampir keseluruhan televisi menanyangkan acara tersebut. Jelas diartikan gosip adalah berita yang belum pasti benar atau bisa dikatakan berita hoax. Namun dengan adanya acara tv tersebut dan khalayak mengkonsumsinya, banyak berita-berita yang

\footnotetext{
${ }^{3}$ Op.cit ${ }^{1}$
} 
tidak disaring oleh khalayak, dan menganggap bahwa berita yang disampaikan adalah fakta. Jika kita sebagai khalayak memilah berita yang akan kita konsumsi, mungkin apa yang ditayangkan pada acara gosip tersebut, tidak mudah kita serap. Jadi bisa dilihat bahwa media massa saat ini tidak netral karena adanya kebebasan kepemilikannya dalam mengatur medianya sendiri.

Berdasarkan observasi yang penulis lakukan terhadap sejumlah orang akan kesadaran masyarakat terhadap media massa yang tidak netral tersebut bisa dilihat bahwasannya mereka tidak merasa dirugikan dengan adanya hal tersebut, dan mereka tidak tahu betul tentang hukum penyiaran yang berlaku di Indonesia. Berdasarkan data yang diperoleh, ada $90,5 \%$ dari 42 orang yang masih menggunakan televisi sebagai media informasi yang mereka konsumsi setiap hatinya. Namun berbanding terbalik dengan kesadaran mereka akan hal yang dilakukan media. Banyak dari mereka berpendapat bahwa mereka tidak merasa dirugikan oleh pihak media atas unsur kepentingan lain media tersebut ${ }^{4}$. Padahal dalam Pedoman Perilaku Penyiaran (P3) dan Standar Program Siaran (SPS) yang dibuat oleh KPI (Komisi Penyiaran Indonesia), yaitu pada BAB VII tentang Perlindungan Kepentingan Publik Pasal 11 ayat (2): Lembaga penyiaran wajib menjaga independensi dan netralitas isi siaran dalam setiap program acara. Jelas dengan adanya pasal tersebut mengatakan bahwa media (lembaga penyiaran) harus bersikap netral, tidak memihak siapa pun. Secara tidak langsung yang dilakukan media ketika mereka memihak suatu pihak (penguasa media untuk berpolitik) mereka telah menghegemoni masyarakat atas yang apa mereka lakukan. Dengan kata lain tindakan yang dilakukan media (penguasanya) adalah proses doktrin secara halus kepada masyarakat, agar masyarakat terbuai akan iming-iming hal yang di tayangkan media (khususnya pada televisi, karena visual lebih menggambarkan suatu pesan), sehingga khalayak tidak merasa

\footnotetext{
4 Shafira Afranisa Yusian. 2018. Analisis

Tanggapan Masyarakat terhadap Media Massa.
}

tertindas, dan menganggap yang dilakukan media tidak berpengaruh dan diterima secara wajar.

Jelas dikatakan oleh Gramsci dan Undang-undang penyiaran yang berlaku di Indonesia, bahwa yang dilakukan suatu media dengan bertujuan citra, pamor, atau kepentingan ekonomi perusahaan adalah tindak tidak sesuai dengan fungsi dan perannya sebuah media massa. Seharusnya media massa berfungsi untuk mengawasi penguasa (mengkritik), namun saat ini media massa malah menjadi alat untuk menyebarluaskan kekuasaannya yang kemudian diterima secara luas oleh masyaratakat dan menjadi sebuah hal biasa di kalangan masyarakat.

\section{KESIMPULAN}

Media massa di Indonesia masih harus dibenahi, karena fungsi dan perannya saja saat ini sudah tidak menjadi media untuk penyampaian informasi saja, kembali lagi soal kepemilikan media. Masih banyak mediamedia massa yang tidak menjalankan fungsi dan perannya dengan baik, jika kita teliti dan sadar akan hal ini, kita akan menjadi individu yang selektif dalam pemilihan tayangan acara untuk diri kita sendiri, keluarga juga orang lain. Agar kita tidak mudah terbuai dan terdoktrin hal yang sudah menjadi ideologi dari para penguasa ini.

\section{Daftar Pustaka}

Buku:

[1] Ardianto, Elvinaro. 2009. KOMUNIKASI MASSA: Sebuah Pengantar. Bandung: Simbiosa Rekatama Media.

[2] Cangara, Hafied. 2016. Pengantar Ilmu Komunikasi: Edisi Kedua. Jakarta: Rajawali Pers.

[3] Maryani, Eni. 2011. Media dan Perubahan Sosial. Bandung: PT Remaja Rosdakarya. 
[4] McQuail, Denis. 2012. McQuail's Mass

Communication Theory: Teori Komunikasi Massa McQuail (terjemahan) Buku 1 Edisi 6. Jakarta: Salemba Humanika.

[5] Rusadi, Udi. 2015. KAJIAN MEDIA: Isu Ideologis dalam Perspektif, Teori, dan Metode. Jakarta: Rajawali Pers.

[6] Tabroni, Roni. 2012. Komunikasi Politik Pada Era Multimedia. Bandung: PT Remaja Rosdakarya.

Internet:

[1] Ardiansyah. Hegemoni Media Terhadap Budaya. Melalui $<$ http://berita.upi.edu/archives/1795> (diakses pada tanggal 01 Januari 2018, Pukul 16.13 WIB).

[2] Septiani, Alfiah. 05 Juni 2016. Pengaruh dan Kontruksi Ideologi Hegemoni Media. Melalui $<$ https://www.slideshare.net/AlfiahSept ianiSiradj/hegemoni-media> (diakses pada tanggal 01 Januari 2018, Pukul 22.05 WIB).

[3] Rosiana. 2013. Komunikasi Massa. Melalui $<$ rosianadaily.blogspot.co.id/2013/04/r esume-komunikasi-massa.html> (diakses pada tanggal 01 Januari 2018, Pukul 18.27 WIB)

[4] Tirto. Menancapkan Mars Perindo lewat Stasiun TV milik Pribadi. Melalui $<$ https://tirto.id/menancapkan-marsperindo-lewat-stasiun-tv-milik-pribadi$\mathrm{nn}>$ (diakses pada tanggal 23 Januari 2018, Pukul 23.49 WIB).

Referensi Lain:

[1] Komisi Penyiaran Indonesia: Pedoman Perilaku Penyiaran (P3) dan Standar Program Siaran (SPS). 